\title{
Gender, Policy, Politics, and Work: Feminist Comparative and Transnational Research
}

\author{
HEIDI GOTTFRIED AND LAURA REESE
}

Wayne State University

\begin{abstract}
This article reviews feminist comparative and transnational research on workplace policy, politics and the state. The first section examines a range of theoretical approaches to the topic. We then present a variety of methodologies for conducting comparative and transnational research on policy developments. Informed by a number of case studies included in the symposium, we explore the dynamics and determinants, both national and supranational, of policy formation and its impacts. Finally, we tease out the implicit and explicit notions of gender equity for future policy analysis.
\end{abstract}

The last two decades of the twentieth century saw the rise of new policies, ranging from equal opportunities and parental and family leave to regulation of working time and sexual relations, that have made the workplace more hospitable to women workers. The collected articles explore the dynamics and determinants, both national and supranational, of such feminist policy formation and its impacts. This symposium contributes to comparative and transnational research on workplace policy, politics, and the state, using feminist perspectives.

A relatively new area of comparative policy research centers around regionalization and globalization of policy formation and gender politics. The first group of articles analyzes the policymaking process that has developed through extranational institutions and the emergence of feminist transnational networks. Both the European Union (EU) and the United Nations (UN) appear as determinants of and arenas for successful feminist coalition building and policy making. Regionalization and globalization can be positive forces to the extent that they present new arenas for feminist actors in governments and society to mobilize around effective women-friendly policies.

Most comparative research aimed at developing a gender perspective has focused on welfare and policy-not on work and employment. In this special issue, several articles integrate labor market studies and occupational analyses with social policy. These articles bring together literatures typically separated into distinct subfields to make visible the impact of policies on gendered labor market patterns and work experiences. Tracing policy processes and outcomes both over time in a single country and across countries, the articles explore how policies influence individual work choices and firm-level practices. And, for US audiences in particular, the explicit comparison of policy formation and outcomes presents a 
picture that can only raise concerns about the state of US workplace policies vis-à-vis other industrialized countries.

After situating the articles in the broader feminist literature, we discuss research methodologies for conducting comparative and transnational research. This review enables us to sort through the contextual factors that matter in explaining national developments and can help to explain cross-national variation. Finally, we tease out the implicit and explicit notions of gender equity to assist the effectiveness of feminist policy research.

\section{FEMINIST COMPARATIVE RESEARCH}

Feminist policy research brings gender into analytical focus, asking "... how gender is constructed in welfare state policies and how these policies are a force in ordering gender relations through an examination of a wide range of contexts" (Sainsbury, 1999). Gender enters both into the framing of policy and its differential impacts. The gender focus sheds light on changing relationships between and within families, states, and markets, and highlights attendant public policy implications. Feminist comparative policy research develops these themes to explain variation across cases. Comparative policy research from a feminist perspective has moved beyond case studies published side-by-side in edited collections devoid of the common theoretical framework needed to make sense of both similarities and differences. Recent studies have compared a single policy area such as child care (Michel and Mahon, 2001), job training (Mazur, 2001), and equal pay (Kahn and Meehan, 1992), and / or have analyzed structural features such as state feminism (Stetson and Mazur, 1995) and welfare regimes (O'Connor et al., 1999) cross-nationally. ${ }^{i}$ Amy Mazur (2002) demarcates four different areas of feminist comparative research: gender and the welfare state, feminist policy formation, state feminism, and women's movements and policy. This symposium cuts across these overlapping approaches and contributes to the broad range of literature on these topics.

Feminist-inspired social policy analyses have refined distinctions within and between clusters of cases (O'Connor et al., 1999; Daly and Lewis, 2000; Gottfried and O'Reilly, 2002; Mutari and Figart, 2001), recasting welfare state typologies in terms of gender-sensitive categories that bring into focus social care, sexuality, reproduction, and the body. Nonfeminist theorists recently have integrated feminist insights into their

'Feminists have established transnational infrastructures for doing research, linking individual efforts, building institutional bridges cross-nationally, and creating virtual research communities. Such affiliative mechanisms foster dialogue among scholars in distant localities and provide the context for intellectual exchange. Transnational research networks compose interpretive communities well suited to carry out comparative and transnational research. The process of globalization provides opportunities and technologies for the establishment of transnational networks. International conferences and computer technologies push the frontiers of networks by intensifying interactions at the local level and by enabling sustained connections through the Internet. 
welfare state models (Korpi, 2000; Esping-Andersen, 1999). Revisiting his three models of welfare capitalism (Esping Andersen, 1990), Gosta Esping-Andersen's (1999) analysis of the postindustrial state borrows the feminist concept of "defamilization" to denote provision of services outside the family by either state or market. However, as Ann Orloff (2002) suggests, he misses another key aspect of feminist theorizing that considers how policies decrease women's economic dependence. On the other hand, Jane Lewis's $(1992,2001)$ concept of the male breadwinner model highlights the gendered assumptions of policymakers about family forms and the ways in which this contributes to the social organization of care. Women's access to benefits has been derived from and mediated by their relationships to men (Orloff, 2002). Current policies supporting women's labor force participation and reconciliation of work and family life have modified, eroded, and weakened the male breadwinner model. Still, the legacy of the male breadwinner model continues to inform policy formation.

Case studies have also contrasted countries with different gender regimes. Feminists have elaborated on Connell's and Walby's (1999) concept of gender regime for comparative and transnational research (Ostner and Lewis, 1995; Walby, 1999). Gender regime refers to "a system of gender relations in the market and household economies, the polity, and in civil society, that includes inter-personal violence and sexuality" (Walby, this issue). Modernization of the gender regime entails women's increasing participation in public spheres and their expanding civil, social, and reproductive rights. Sweden appears to have moved the furthest along the continuum toward a public gender regime, followed by the US, the UK, and then Germany and Japan, who have the most domestic gender regimes.

Feminist policy formation overlaps with the state feminism approach: both analyze policy processes and structures internal to the state. They attempt to unravel the comparative puzzle to explain the extent to which the contemporary welfare state pursues feminist/women-friendly policies (Mazur, 2001, 2002; Stetson and Mazur, 1995; Kahn and Meehan, 1992). The state feminist approach first noted the emergence of women's policy machineries and examined the array of institutional arrangements inside the state devoted to women's policy questions across a range of issues and countries and they asked what accounts for the effectiveness of feminist policies to improve women's social status (Stetson and Mazur, 1995). Feminist comparative policy theorists credited the role of femocrats $^{\mathrm{ii}}$ and feminist organizations in bringing feminist issues to bear on political institutions at multiple levels of polities (Mazur, 2001). Extending this approach further, Mazur (2002) uses the secondary literature to elaborate eight subsectors of feminist policy to explore whether, how, and why governments pursue purposely feminist actions. Three of the eight

\footnotetext{
iA Australian feminists coined the term "femocrats" to describe feminist state bureaucrats who work in women's policy offices and who advocate gender equality policies (Stetson and Mazur, 1995; Mazur, 2001).
} 
subsectors, specifically, equal employment, reconciliation of work and family life, and sexuality and violence policies, are particularly relevant to the study of gender, policy, and work.

These approaches, although sharing common concerns, have different foci and produce different understandings of the state. Welfare state theory typifies national cases through excavation of regime and/or policy logics. Contra-welfare state theory, feminist policy formation, and state feminist approaches treat the state as internally differentiated structures and processes (Stetson and Mazur, 1995; Mazur, 2001). Neither expects coherence nor unity across policy areas, yet state feminists avoid welfare state theories' generalizing about national policy styles.

Feminist theorizing also explores how women's mobilization, either through autonomous movements or within larger organizations (such as unions) and political parties, affects the type, locus, and effectiveness of policy. Working women's self-organization, as indicated by their absolute increase and relative share in trade unions, has pushed the development of equality policies (Walby, this issue). Peggy Kahn and Elizabeth Meehan (1992) have found that unions have influenced the path of equal pay initiatives; the strength of the labor movement affects change on the national level in the UK and it is largely confined to the public sector in the US. Unions have not always recognized the gender impacts of issues that are not framed in gendered terms such as job training (Mazur, 2001). Women's movements also are adopting new spatial forms of politics through transnational networks. Networks as organizational forms aggregate micropolitical processes, mobilize horizontal channels of information, foster communicative action, and facilitate pooling and sharing of resources over time and space (Lenz, 1999). Policy transfer has occurred through international organizations (in particular, the UN women's conferences, specifically Beijing and Beijing plus) and cross-fertilization among women's groups. Non-governmental Organizations and transnational women's networks translate and transform feminist goals into actual policy-making processes at multiple levels.

Feminist comparative policy research represents a rich and growing field of study. The integration of gender into policy research illuminates areas often hidden from view and indicates differential impacts between men and women and among groups of women. Through examination of changing relationships within and interaction between private and public spheres, feminist analyses examine how policies affect intimate practices in everyday experiences to broaden social changes.

\section{METHODOLOGY}

These articles present original research on policy, politics, and work, and they evaluate some of the most current policy developments crossnationally. As a whole, they contain an extensive bibliography on empirical feminist policy issues and the theoretical literature used by feminist 
comparative policy scholars. A variety of research methods are used, including process tracing, life-course analysis, correlational analysis, and the comparative method. All of the articles examine processes in flux, over an extended period of time, either through overtly longitudinal analysis of data or by process tracing over time. Examination of processes over time is central to understanding and theorizing policy processes and dynamics in any setting.

\section{Doing Comparative and Transnational Research}

The impulse for comparative study extends beyond the usual and more narrowly bounded research communities. Comparative research increasingly dominates earlier styles of area studies conducted on the basis of in-depth analysis of a single case. A growing recognition that real qualitative changes have altered political-economic institutions and that greater interconnectedness between subnational, national, and supranational levels increasingly compels consideration of comparative and transnational studies that pay close attention to relationships between and within cases. Comparative research must be distinguished from trans-border or transnational research: comparative research may or may not be transnational; the former does not necessarily entail comparisons between more than one country/region.iii A study may compare subnational units within a country or may examine a process over time within a single case.

Richard Locke and Kathy Thelan (1995) designed research around "contextualized comparisons" by conducting in-depth case studies analyzed in relationship to each other. This approach typically uses "thick" description and "thick" theory toward developing a comparative contextualized account (c.f., Thelen, 1999). Such contextualized comparisons are sensitive to both history and culture, and

... demonstrate how various international trends are not in fact translated into common pressures in all national economies but rather are mediated by national institutional arrangements and refracted into divergent struggles over particular national practices... Contextualized comparisons are meant not to displace but rather to complement traditional matched comparisons; they bring new insights to labor scholarship by highlighting unexpected parallels across cases that the conventional literatures sees as very different and, conversely, by underscoring significant differences between cases typically seen as "most similar" (emphasis in the original, 228)... By focusing on the way different institutional arrangements create different sets of rigidities and flexibilities, we can identify the range of possible "sticking points" or potential sources of conflict between labor and management in a particular country (Locke and Thelen, 1995).

However, the contextualized comparative method can reify national institutions in its attempt to look deeply at cases. As several of the sympo-

\footnotetext{
iiiBarbara Stallings made this distinction during a workshop on the third case sponsored by the Social Science Research Council in cooperation with the Japan Foundation, 1999.
} 
sium articles deploy to good effect, contextualized comparisons detail factors that lead to divergent pathways and convergent policy directions.

Comparative and transnational researchers have acknowledged regionalization of policy formation and practice, especially for the study of the EU. To study the EU vis-à-vis member states, political theorists consider the relationship between national and supranational (including regional) levels and units of analysis. The metaphor of "multilevels" was introduced by Wolfgang Streeck (1998) to analyze the relationship between national and supranational governance institutions Europewide. However, the EU should not be studied in isolation, despite its considerable peculiarities. The EU possesses characteristics loosely resembling those of other political systems, and these systems can usefully be compared. For example, the multi-tiered decision making by the European Commission is likely to create quite distinctive pressures and constraints on social policy development by national actors (Pierson and Liebfried, 1995), as suggested by the first set of papers. A different approach by Peter Katzenstein (1999) argues that "the character of core polities and the different connections to their regional environments is consequential for the kind of regionalism that emerges." He chooses Germany and Japan because they exemplify regional states central to the evolution of European and Asian regions, respectively. A productive approach analyses "the recalibration of national and international factors in regional settings that connect both realms."

More comparative research stretches beyond the usual western cases. One innovative approach by T.J. Pempel (1998) derives a puzzle from comparative analysis of welfare states, asking how can we explain phenomenal economic growth, low unemployment, and the low degree of social inequality given that the postwar features of Japan deviated from patterns noted in European welfare states? Pempel situates Japan in broader contexts to analyze particular changes within Japan and to revise understandings of welfare states typically based on either intra-European comparisons or US and European comparisons. As a nonwestern, industrialized country, Japan can reveal comparative insights about significant similarities and differences that may go unnoticed when studying countries sharing a common historical background. Ilse Lenz's article, among other feminist policy theorists (Peng, 2001; Gottfried, 2000), brings knowledge of Japanese developments to inform the transmission of feminist ideas and translation into policy across countries. Transnational women's networks figure centrally in these accounts.

\section{Globalization, Regionalization, and Policy Formation}

The comparative policy development literature increasingly pays attention to globalization, ${ }^{\text {iv }}$ changing the context and content of policy forma-

${ }^{i v}$ Globalization affects a growing number of chains of economic, social, cultural, and political activity that are world-wide in scope and an intensification of levels of interaction and interconnectedness between states and societies (Amin, 1997). 
tion and implementation. Many analyses of globalization have assumed that there is a process of deregulation as national economies attempt to compete in increasingly globally integrated markets. The emphasis on deregulation has occurred in part because of the absence of a feminist analytics. Specifically, feminist analyses uncover the process of re-regulation and integrate agency with the more structural approaches that have traditionally been used in the analysis of employment and of globalization. In this symposium, Lenz and Walby challenge gender-blind globalization theories in their analyses of policy developments for workplace gender equity. In these articles, they argue against the standard view that globalization is principally associated with de-regulation. Walby presents evidence suggesting that many of the new employment forms, which have been associated with a new economy, are actually related to regulation or re-regulation of the workplace. The gender lens enables a clearer understanding of the way in which globalization involves not only deregulation, but also re-regulation, and how the larger forces of economic and societal globalization can affect the nature and quality of workplace policies.

Globalization has altered the sites, the subjects, and the ways of doing politics and has rescaled political institutions and arenas to expand the field of politics in which women's movements can make claims. The first two articles in the symposium also effectively integrate concern with networks and agency with the more structural approaches. They discuss the differential way in which transnational networks can leapfrog national boundaries, and they document the way in which transnational feminist networks have been developed at the global and national levels as a formally hidden part of globalization. Analyzing the agency of global feminist networks enables Lenz to examine the diverse nature and impact of globalization on two countries, Japan and Germany. Globalization is seen as an open-ended process that is subject to negotiation by a variety of political actors. This has important policy implications because changing regulations are framed by global connections, with the UN system and its conferences as a key element in the diffusion, development, and hybridization of gender equity policies. The comparison raises several questions: How and why are countries like Japan and Germany differently affected by global feminism? Is Germany buffered from the global by the EU, whereas Japan is not? And, how does the global system frame the possibilities for and nature of workplace policies that address gender differences?

The EU has opened a new political space for organized interests to influence policymaking at the national and subnational level. The shift from a national to a multilevel governance structure avails new opportunities for democratic politics especially for those groups formerly excluded from, or marginalized in, corporatist structures (Bergqvist, 2001). Women's groups have found room to maneuver in local and national politics due to changing regulations on the EU level.

As Walby (1999) has argued in earlier research, the EU constitutes an emerging polity that has had a significant impact on modernizing gender 
regimes both at the EU level and within member nations. The EU is seen as a major driving force in developing the wide range of policies that address women's inferior position in paid labor. Julia O'Connor (2001) reaches a similar conclusion in saying, "The Community has brought about changes in employment practices which might otherwise have taken decades to achieve. Irish women have the Community to thank for the removal of the marriage bar in employment, the introduction of maternity leave, greater opportunities to train at a skilled trade, protection against dismissal on pregnancy, the disappearance of advertisements specifying the sex of an applicant for a job and greater equality in the social welfare code" (cited in Orloff, 2002). For the UK, national politics, particularly the election of the Labor Party, may have contributed to the enactment of women-friendly policies. However, it is not at all clear whether or not New Labour would have pursued a proactive feminist policy agenda in the absence of EU directives.

Alison Woodward maps policy transmission from various international and supranational institutions and systematically studies gender mainstreaming policies as they have been transformed and translated into national and subnational practices. The case of "gender mainstreaming" illustrates both the transformative promise and pitfalls of state feminism. Implementation of gender mainstreaming varies from locale to locale within countries as well as across countries in the EU. One reason for this is the ambiguity of the language of mainstreaming itself. This ambiguity is evident in the confusion over the meaning of the term and the wide disparity of practices under the same rubric. The language is ambiguous in another sense; mainstreaming is a policy tool that attempts to use the "language of the state against the state." Thus, the ambiguity or paradox leads to the same policy tool being viewed as both an innovation and a deception by different actors and in different places. The scope and scale of gender mainstreaming seems to be broadest where femocrats exercise the "power of definition," which is the ability to define what gender mainstreaming means in practical terms. Women's policy machineries are also important to the success of feminist policies. Although not all women's policy machineries have the mission of mainstreaming, many of these agencies and femocrats are involved with effective mainstreaming practices.

Woodward's cautionary tale suggests that gender mainstreaming as an instrument and a discourse can either promote gender equality or serve as window dressing. As a consequence, equal opportunity offices should not be abandoned, but rather supplemented by this new policy tool kit. Gender mainstreaming has both innovative and deceptive potentials, depending on the success of gender politics (also, see Lenz, 1999) and the issue of nomenclature or "naming" has important policy implications at both a symbolic and practical level. The language of debate about the appropriate policy frame for gender and workplace policies carries embedded implications for policy outcomes. 
In her comprehensive and up-to-date review of parental leave policies in this issue, Linda Haas compares the fifteen EU countries in terms of key policy features, including the length of leave, payment, flexibility, and incentives for fathers. Five clusters of countries range from traditional to egalitarian based on the extent that each parental leave policy helps mothers combine work demands and family responsibilities. Parental leave and maternity programs play an important role in allowing women to take up employment on more equitable terms by guaranteeing income security when they must attend to care giving. In countries where leave provisions are generous, but other employment supports are not well developed, leave may reinforce traditional division of labor and women's nonemployment (as in Germany and Italy). A major shift in policy debates among EU nations discussed by Haas has been the recognition of the need for incentives to encourage fathers' participation in caring labor. Sweden comes closest to an egalitarian society in that policies effectively provide male employees incentives to share in the care of young children. In Sweden, the nontransferable entitlement to fathers has not only significantly increased men's use of the benefit, but also has positively affected their time at work. The persistence of sex-based occupational segregation not only indicates trouble in Swedish feminist paradise, but also points to the deeply entrenched gender power relations resistant to policy innovation from above.

The EU has advanced regulation, via its legally binding directives on equal treatment of men and women and in the Treaty of Amsterdam, and the more recent development of "gender mainstreaming." To what extent is "Europeanization" of policy formation (and identity formation) taking place (see Liebert, 2000)? There seems to be greater obstacles in the way of building a social policy union that can harmonize historically different pathways taken by member states than faced by monetary union architects of the Euro-zone. Past policy frameworks continue to shape implementation and interpretation of directives issued by various bodies of the European Commission. Still, the effects of EU directives can clearly be seen in changes in workplace policies, suggesting that regionalized policy stances can impact member nations. At the EU level, the Directive on Parental Leave in 1996 has pushed countries to adopt leave policy. The comparison also indicates that parental and family leave regulations have advanced further than childcare support, highlighting the underdevelopment of a social infrastructure of care services, with the exception of Sweden. The EU's failure to issue a binding directive on childcare has left the question of reproductive work to be resolved in the mixed economy of privately and publicly provided care (Gottfried and $\mathrm{O}^{\prime}$ Reilly, 2002). Still, EU institutions, ranging from the European Commission, European Parliament, and the European Court of Justice, appear to be more open to feminist input and the emergence of supranational state feminism. One consequence of multilevel governance is that women's groups are mobilizing across borders in a wider field of politics (Lenz, this issue). 


\section{Reconciliation of Work and Family Life: Maternity, Parental, and Family Leave}

One of the most far-reaching workplace policies has been the extension of parental and family leave. Its initial conception as maternity leave enabled mothers to take time off before and after childbirth. In response to increasing female labor force participation, especially among mothers with young children, and changing norms about work and family, all industrialized countries have moved from some sort of maternity leave to either parental or family leave policy. The articles here examine the least-developed Family and Medical Leave Act (FMLA) in the US, as well as family leave in Germany. The US and Germany contrast with the model family leave policies in Sweden, which pioneered parental leave in 1974. As the national cases illustrate, social policy influences paths to women's employment and shape the patterns of women's employment, especially the continuity of their participation over the life course (Orloff, 2002).

Karin Gottschall and Kate Bird offer an innovative contribution to welfare state theory by combining life course and labor market approaches to better understanding how policies affect the patterns of women's labor force participation and the gendered division of labor. The public educational and dual vocational training systems that are unique to Germany are important background conditions. The former because of the short hours and lack of aftercare programs and the latter because of the gender bias in training toward men in manufacturing and devaluation of traditional women's work in the service sector. Through empirical analysis, the authors construct motherhood cohorts based on the birth of the first child in order to determine the impact of the four important policy reforms (mother allowance, maternity leave, family leave, and parental leave) on women's work choices and chances in Germany. The progression from mother allowance to family leave has had the effect of shoring up the male breadwinner, female career model despite the diversification of family forms and increased female labor force participation. Essentially, leave regulations have standardized a "baby break" among women. Thus, the findings are contrary to the standard employment relation and corresponding labor market theory, which never fully addressed women's labor force positions and participation. Policy has likewise tended to address issues that affect men in core manufacturing sectors. Furthermore, Gottschall and Bird's analysis indicates a strong path dependency to the development of regulation, and, perhaps more critically, shows how changes in workplace policy can directly impact, for good or ill, leave-taking behaviors on the part of female employees.

Steve Wisensale's symposium article on the history of the FMLA implies that the US is an outlier when compared with other industrialized nations. The timing of the regulation in the US lagged behind other countries, although debate over leave began much earlier in 1984. It was 
the US Supreme Court decision of January 13, 1987 that brought to light inconsistent provisions between, and minimal coverage of, state and federal laws. At issue was the conflict between many state law requirements that pregnant employees be treated in a special manner and the federal mandate that they be treated the same as other workers. When the US Supreme Court upheld California's maternity law providing for special benefits to pregnant women workers, feminists directed their attention to arguments both for and against special treatment and the framing of pregnancy as a disability. The FMLA is both a continuation and a departure from earlier laws: it is a continuation as an individualbased entitlement, but it is a departure in providing a federal standard, albeit with significant exemptions, for family-based leave. The policy differs from other countries not only in the lack of remuneration, but also by combining leave for child and elderly care. Furthermore, the case highlights the impact of the US federal system on the implementation of workplace policy that allows for significant variation among states in the quality and content of family leave regulations. This article reveals that retrenchment resulted when the states implemented federal law.

On the other hand, Heidi Berggren's analysis of the male breadwinner model in the US suggests that some progress is being made in bringing the reality of gender and work more in line with feminist policy. Over time, it appears that the benefit structures of some male- and femaletyped occupations are becoming more similar with respect to generalized insurance, health, and vacation benefits. Women in profession such as nursing receive benefits in line with skilled blue-collar workers such as mechanics. Nurses have a high-level of organization in unions or professional associations and have experienced labor shortages that may account for the generous benefits and relatively high wages. To what extent do these results apply more generally across occupations and professions? Aggregate-level data indicate that women workers, especially in the growing service sector, earn low wages and often forego benefits. Some portion of professional women's gains may be the result of falling wages and erosion of benefits among male blue-collar workers who were relatively well paid in the past. ${ }^{\mathrm{v}}$ It also appears that several critical health benefits, i.e., hospitalization, surgical, and catastrophic medical, in "female professions" remain lower, thus leaving a barrier to an effective shift from male to universal "breadwinning."

The policy examples in the symposium suggest looking at the extent to which welfare states promote familialism versus women's employment, that is, the relative extent of defamilization. Defamilizing policies make possible relatively high female employment levels and generate employment by increasing demands for childcare service, which are public in Nordic countries and France, and are market-based in the US 
and Canada. In many countries, care is provided privately with little development of public services, but general support to families with children is high (as in Germany and Japan; Orloff, 2002). Gottschall and Bird suggest that another way to characterize differences relates to whether care is organized either as a transfer-intensive system as in Germany or as a service-intensive system as in Sweden. Sweden has retained and strengthened universalistic, egalitarian principles despite neoliberal pressures to privatize. Privatization of childcare has not abrogated public responsibilities, but rather, as Christina Bergqvist and Anita Nyberg (2001) argue, "private" childcare is "publicly regulated and financed" in Sweden. The Swedish state, despite devolution of responsibility from the national to the municipal level, has spurred the growth of high-quality childcare services (Bergqvist and Nyberg, 2001). By contrast, Germany "more readily gives direct financial assistance to those taking on the tasks of child or elder care in the family, rather then investing in an expansion of public social services" (Gottschall and Bird, this issue). To ensure quality and more universal access, Sweden moved pre-school from the Ministry of Health and Social Affairs to the Ministry of Education and Science in 1996 (Bergqvist and Nyberg, 2001), whereas Germany has kept childcare separate from public education. Japan offers an example of a different mix of private provision with public guidance; relaxation of state control in 1996 freed childcare from regulation to encourage the expansion of private, for-profit child care (Peng, 2001). The result has been more, but inadequate, childcare facilities with hours that do not accommodate full-time work schedules for both working parents in both Germany and Japan. Sweden represents the case with the most extensive degree of defamilization.

Furthermore, Gornick, Meyers, and Ross distinguish between support for mothers' employment, measured in terms of policies that provide care for young children and allow women to maintain employment continuity (through paid leaves), from general support to families with children (cited in Orloff, 2002). Care for children under 3 years of age, which is essential for mothers' employment, is less developed outside of Nordic countries and France. A higher percentage of mothers drop out of the labor force to take care of young children in countries like Germany and Japan, who provide general family support.

Care has shifted to some extent to institutions other than the families, yet policies often do not attend to either the quality of care or the quality of care work (in terms of wages and benefits). Care work, especially in the private sector, often pays low wages and is undervalued. The quality of care work is likely to be associated with the quality of care.

\section{Regulating Sexual Relations in the Workplace}

Equal opportunity and antidiscrimination policies were "a watershed in the history of welfare state egalitarianism" (Esping-Andersen, 1999). Studies show that success, implementation, and enforcement of these 
policies has varied widely at the organizational level (Reese and Lindenberg, 1999; Grauerholz et al., 1999) as well as cross-nationally due to differences in legal systems and legal strategies. Katrina Zippel compares two cases to tease out the determinants of feminist policy outcomes and to account for different implementation of policy approaches to sexual harassment in Germany and the United States. Legislation and enforcement practices of sexual equality law are embedded, respectively, in German labor law in the form of workers" protection laws versus civil rights law in the US. Thus, in the latter, the dynamics of implementation have emphasized individuals" legal redress, individual reporting, and lawsuits, which have affirmed employers" responsibilities to prevent sexual harassment by institutionalizing policies and educational programs. In contrast, in the absence of strong antidiscrimination laws in Germany, the implementation of policies against sexual harassment depends on the political will of unions, employers, and emerging state equality offices for women-offices that are often stronger in the public sector (see Gottfried and O'Reilly, 2002). The approaches to sexual harassment mirror the different ways that women's movements have pursued their agendas in the two countries (Young, 1999). US women's groups have relied on the court for extending rights, whereas German women's groups have worked through organized political actors (political parties and unions) to affect change. Thus, the courts have been an important mechanism for social action in the US absent other political vehicles extant in Germany and other European countries.

Zippel points to the legal system as significantly affecting the implementation of sexual harassment policies. For example, large settlements, either through individual or class action suits, are rare in Germany. The legal arena exerts less pressure on German employers to take action on issues of sexual harassment or discrimination. Class action suits have been more successful in the US in term of settlements than in more collectively oriented countries like France or Germany. In Japan, a US-style legal strategy is more evident whereby women's legal advocates bring suits against companies. These widely publicized trials serve a symbolic function to shame companies and the state into addressing sexual harassment more than an attempt to win large monetary rewards.

Different political opportunity structures have shaped womens' "access" to the state and/or courts, and thus also the priorities and agenda of women's movements, thereby influencing whether sexual harassment policy came mainly through changes in case law (as in the US) or by the passage of new laws (as in Germany). In both the US and Germany, the federal systems of government have created tensions between state and national regulations. In the US, some states have enacted more extensive provisions and have experimented with initiatives aimed at paying a portion of family leave, but no state mandates paid leave. Similarly, Lenz notes the more progressive development of Equal Opportunity Law in the federal state of Nordrhein Westfalen, with a long history of progressive politics. 
Finally, Germany reappears in many of these papers as a socially conservative welfare regime undergoing change, whereas the UK and US are liberal welfare regimes who appear to diverge with respect to the development of social rights and civil rights, respectively. US feminists have tended to work to make traditional breadwinner positions in the workforce available to women (Berggren, this issue). This is related to the fact that the US political context has been quite encouraging to liberal feminist civil rights claims, such as for equal opportunities, in terms of available allies and established political discourse, but less open to claims for social rights such as paid parental leave or public child care services. Thus, US feminist have supported political interventions that encourage private provision of services such as tax credits for childcare, equal opportunity regulation of employment, and affirmative action ( $\mathrm{O}^{\prime} \mathrm{Connor}$, Orloff, and Shaver, 1999).

\section{CONCLUSION: FEMINIST STANDARDS OF GENDER EQUITY}

A rights revolution has spread across the globe, yet the extension of formal equality has not eliminated gender inequality. Feminist research attempts to evaluate the extent to which policies make societies more gender just/equal. However, there is not a single feminist standard of gender equity or even agreement over what constitutes a women-friendly policy. Women-friendly policies should promote feminist goals and principles of gender justice by breaking down gender-based hierarchies (Mazur, 2002), they should enhance women's independence and increase their capacity to support and sustain an independent household, they should empower women, and they should end unequal burdens of labor (Orloff, 2002).

Nancy Fraser (1997) develops a typology of extant work/family models and proposes a feminist model of gender equity. She designates Sweden and the US at opposite ends of the "Universal Breadwinner Model," in which everyone carries out paid work and care provided by either state or market, respectively. At the national level, the more egalitarian policy framework in Sweden has produced the most womenfriendly model. Even as policy formation and implementation devolve to municipal levels, Sweden has maintained a public commitment to social care provision. As the symposium articles by Haas and Wisensale indicate, Sweden has the best family leave and the US has the worst. Despite decades of changing worker demographics and much rhetoric, particularly in the US, about gender equality in the workplace, it is ironic that the US (along with the former West Germany) remains very close to the male breadwinner end of the spectrum when actual workplace policy is considered (Bird and Gottschall, this issue).

Fraser specifies two other models. She notes that the "Parent Worker Model" for solo parents, which approximates the Swedish approach, entitles the care-taking parent(s) to care services for dependents to enable 
them to engage in the labor market full-time. However, the Universal Breadwinner Model promotes the male citizen-worker and implicitly denigrates informal caring work. These incentives may push the model further toward a "Universal Care Model" as characterized by dual earning and care sharing. Such a model, according to Fraser, revalues caring work and rejects the demand that women assimilate to maledefined institutional norms and deconstructs the norms by combining breadwinning and care-giving and the associated opposition between bureaucratized public institutional settings and intimate private domestic settings. How to achieve this utopian model is less clear.

A less totalizing approach focuses on a single policy area. Zippel (this issue) develops a third category for evaluating the success of sexual harassment policy, going beyond advantages and disadvantages of either the US or the German model. The case study shows that both the US and German models are deficient when evaluated against a norm of gender equity. An effective policy aims to protect women's rights to sexual selfdetermination and nondiscrimination, and interventions should combine both individual and group based responses and remedies, offer multiple routes and forms of complaints, and provide training that changes gender workplace culture.

It is not possible to sketch either a blueprint of or a pathway for realizing gender equality. The articles here, among other feminist comparative research, critically evaluate existing policies for transforming asymmetrical gender relations and they suggest feminist principles of and strategies for achieving gender equity.

Taken as a whole, this symposium suggests substantive change, but also continuity in the pathways of contemporary workplace policy. On the one hand, all of the countries analyzed here have extended regulation over gender relations in the workplace. On the other, there appears to be a high degree of path dependency. Historical, economic, social, and legal systems continue to color workplace policies in the nations considered here. These systems lead to differences in the nature of workplace policies among industrialized nations and within nations with federal systems.

As the articles show, the increasingly public gender regime with a dual earner family has not yet up-rooted the female career arrangement. Sweden has moved closest to the gender equity model, whereas Germany and Japan continue to rely on women's unpaid labor for care in the family saving taxpayers' money that would otherwise be absorbed via expensive institutional care. The United States, on the other hand, has lagged behind many EU nations in the implementation of fully gender-neutral and feminist policies in the workplace. The extent that this is due to national or political systems and culture and/or the absence of pressure from regional or global bodies is unclear. Some of the causal factors in development of effective feminist policy include the increased rates of women's unionization, legal systems, gender equality politics, modern- 
ization of gender regimes, changing territorial division of power, attitudes and norms of nonfeminist bureaucracy, levels of government expertise, EU gender equality policy and other directives, and transnational feminist networks. The issues raised and the comparisons posed in this symposium provide essential input into the debate surrounding gender and workplace policy by making explicit often implicitly constituted systems of gender relations at the societal and workplace levels. Policy debates can only become more refined and better informed as a result.

\section{REFERENCES}

Bergqvist, Christina. 2001. "Gender (in)equality and the transition of Swedish corporatism." Paper presented at the European Center for Policy Research Conference, Canterbury, UK, September.

Bergqvist, Christina and Anita Nyberg. 2001. "Alive and Fairly Well: Welfare State Restructuring and Child Care in Sweden." In Rianne Mahon and Sonya Michel (Eds.), Child Care and Welfare State Restructuring: Gender and Entitlement at Crossroads. New York: Routledge.

Crouch, Colin and Wolfgang Streeck. 1997. Political Economy of Modern Capitalism: Mapping Convergence and Diversity. London: Sage.

Daly, Mary. 2002. "Care as a Good For Social Policy," International Social Policy. 31(2): 251-270.

Daly, Mary and Jane Lewis. 2000. "The Concept of Social Care and the Analysis of Contemporary Welfare States," British Journal of Sociology. 52(2): 281-298.

Esping-Andersen, Gosta. 1990. The Three Worlds of Welfare Capitalism. Cambridge: Polity.

- 1999. Social Foundations of Postindustrial Economies. Oxford: Oxford University Press.

Fraser, Nancy. 1997. Justice Interruptus: Critical Reflections on the "Post socialist" Condition. London: Routledge.

Gottfried, Heidi. 1998. "Beyond Patriarchy? Theorising Gender and Class," Journal of the British Sociological Association. 32(3): 451-468.

. 2000. "Compromising Positions: Emergent Neo-Fordisms and Embedded Gender Contracts," The British Journal of Sociology. 52(2): 235-259.

Gottfried, Heidi and Jacqueline O'Reilly. 2002. "Re-regulating Breadwinner Models in Socially Conservative Welfare Regimes: Comparing Germany and Japan," Social Politics. 9(1): 29-59.

Grauerholz, Elizabeth, Heidi Gottfried, Cynthia Stohl and Nancy Gabin. 1999. "There's Safety in Numbers: Creating a Campus Advisers" Network to Help Complainants of Sexual Harassment and Complaint-Receivers," Violence Against Women. 5(80): 950-977.

Hoskyns, Catherine. 2001. "Gender Politics in the European Union: The Context for Job Training." In Amy Mazur (Ed.), State Feminism, Women's Movements, and Job Training: Making Democracies Work in a Global Economy. Routledge: New York.

Kahn, Peggy and Elizabeth Meehan. (Eds.). 1992. Equal Value/Comparable Worth in the UK and the USA. New York: St. Martin's Press.

Kitschelt, Herbert Lange, Peter Marks and John Stephens. 1999 Continuity and Change in Contemporary Capitalism. Cambridge: Cambridge University Press.

Korpi, Walter. 2000. "Faces of Inequality: Gender, Class and Patterns of Inequalities in Different Types of Welfare States," Social Politics 7(2): 127-191.

Lenz, Ilse. 1999. "Globalization and the Formation of Semi-Publics." International Conference on Rationalization, Organization, Gender Proceedings." Sozialforschungsstelle Dortmund. 
Lewis, Jane. 2001. "The Decline of the Male Breadwinner Model: Implications for Work and Care," Social Politics. 8(2): 152-169.

. 1992. "Gender and the Development of Welfare Regimes," Journal of European Social Policy. 2: 159-73.

Liebert, Ulrike. 2000. "Europeanizing the Military: The ECJ as a Catalyst in the Transformation of the Bundeswehr." Paper prepared for a Joint Workshop on Europeanization in Transatlantic Perspective, Institute for European Studies, Cornell University and Jean Monnet Centre for European Studies, University of Bremen, Bremen.

Locke, Richard and Kathleen Thelan. 1995. "Apples and Oranges Revisited: Contexualized Comparisons and the Study of Comparative Labor Politics," Politics and Society. 23(3): 337-367.

Katzenstein, Peter. 1999. "Regional States: Japan and Asia, Germany in Europe." Paper prepared for "Germany and Japan: The Future of Nationally Embedded Capitalism in a Global Economy," Max-Planck Institute, Cologne, Germany, June.

Mazur, Amy. 2001. "Introduction." In Amy Mazur (Ed.), State Feminism, Women's Movements, and Job Training: Making Democracies Work in a Global Economy. New York: Routledge.

. 2002. Theorizing Feminist Policy. Oxford: Oxford University Press.

Mutari, Ellen and Deborah Figart. 2001. "Europe at a Crossroads: Harmonization, Liberalization, and the Gender of Work Time," Social Politics. 8(1): 36-64.

O'Connor, Julia, Ann Shola Orloff and Sheila Shaver. 1999. States, Markets, Families: Gender, Liberalism and Social Policy in Australia, Canada, Great Britain and the United States. Cambridge, UK: Cambridge University Press.

Orloff, Ann Shola. 2002. "Gender Equality, Women's Employment: Cross National Patterns of Policy and Politics." Paper prepared for Workshop on Welfare, Work and Family: Southern Europe in Comparative Perspective. Florence, Italy: European University Institute.

Ostner, Ilona and Jane Lewis. 1995. "Gender and the Evolution of European Social. Policies." In Stephen Leibfried and Paul Pierson (Eds.), European Social Policy: Between Fragmentation and Integration. Washington, D.C.: The Brookings Institution.

Pempel, T.J. 1998. Regime Shift: Comparative Dynamics of Japanese Political Economy. Ithaca: Cornell University Press.

Peng, Ito. 2001. "Gender and Generation: Japanese Child Care and the Demographic Crisis." In Rianne Mahon and Sonya Michel (Eds.), Child Care and Welfare State Restructuring: Gender and Entitlement at Crossroads. New York: Routledge.

Pierson, Paul and Stephan Leibfried. 1995. "Multi-tiered Institutions and the Making of Social Policy." In Stephen Leibfried and Paul Pierson (Eds.), European Social Policy: Between Fragmentation and Integration. Washington, D.C.: The Brookings Institution.

Reese, Laura and Karen Lindenberg. 1999. Sexual Harassment Implementation in the Public Sector Workplace. Thousand Oaks, CA: Sage Publications.

Sainsbury, Diane. 1999. Gender Regimes and Welfare States. Oxford, UK: Oxford University Press.

Sassen, Saskia. 1996. "Toward a Feminist Analytics of the Global Economy," Indiana Journal of Global Legal Studies. 4(1): 7-41.

Stetson, Dorothy McBride and Amy Mazur. 1995. "Introduction." In Dorothy McBride Stetson and Amy Mazur (Eds.), Comparative State Feminism. Thousand Oaks, CA: Sage Publications.

Streeck, Wolfgang. 1998. "The Internationalization of Industrial Relations in Europe: Prospects and Problems," Politics and Society. 26(4): 229-459.

Thelen, Kathleen. 1999. "Historical Institutionalism in Comparative Perspective," Annual Review of Political Science. 2: 369-404. 
Walby, Sylvia. 1999. "The New Regulatory State: The Social Powers of the European Union," British Journal of Sociology. 50(1): 118-140.

Young, Brigitte. 1999. Triumph of the Fatherland. Ann Arbor: University of Michigan Press.

\section{ABOUT THE AUTHORS}

Heidi Gottfried is Associate Professor of Labor in the College of Urban, Labor, and Metropolitan Affairs at Wayne State University. Her MA in sociology is from the University of Michigan-Ann Arbor, and her Ph.D. was received in 1987 from the University of Wisconsin-Madison. Over the past several years, her work, funded by ASA/NSF, DAAD, and SSRC-Abe, has focused on comparative analysis of flexible employment practices and regulation in the US, Germany, Sweden, and Japan.

Laura A. Reese is a professor in the Urban Planning Program and a fellow in the Fraser Center for Workplace Issues, College of Urban, Labor, and Metropolitan Affairs at Wayne State University. She has published on urban politics, local economic development, comparative urban policy, and public personnel management. Her most recent books are The Civic Culture of Local Economic Development (with Raymond Rosenfeld) and Implementing Sexual Harassment Policy (with Karen Lindenberg) both with Sage Publications. Her current research interests focus on further exploration of local civic cultures in the US and Canada, comparative studies of urban consolidation and metropolitan governance, and the identification and implementation of effective sexual harassment policy.

We would like to thank David Feldman and two anonymous reviewers for their detailed comments and guidance on the symposium. 